\title{
Transfer of Dietary Chlortetracycline into Eggs and its Disappearance from Eggs and from the Liver
}

\author{
Minoru Yoshida*, Daisaku Kubota*, Shoichi Yonezawa**, \\ Hisashi NaKamura**, Ryozo Yamaoka** and Haruo Yoshimura** \\ * National Institute of Animal Industry, Chiba-shi \\ ** National Veterinary Assay Laboratory, Kokubunji-shi
}

In the series of studies on the transfer and disappearance of dietary antibiotics in eggs, it was found that the behaviour of two macrolide type antibiotics with lactone rings in their chemical structure, i. e. spiramycin ${ }^{1)}$ and tylosin ${ }^{2}$, was different, the former being easier to be absorbed and transferred into eggs and staying longer than the latter. The behaviour of oxytetracycline reported in the previous paper ${ }^{3)}$ resembles rather that of tylosin than spiramycin.

In this paper, the behaviour of chlortetracycline, another tetracycline antibiotic widely used as feed ingredient, was reported.

\section{Exprimental}

A premix of chlortetracycline, abbreviated as CTC hereafter, containing $88,800 \mathrm{ppm}$ of CTC, was mixed in the basal diet at the level of $8,000 \mathrm{ppm}$. The composition of basal diet was the same as used in the previous experiments ${ }^{1 \sim 3)}$. The supplementation of the CTC was made by replacing wheat bran in the basal diet.

Total 35 white Leghorn hens of about 8 months old were divided into a group of 10 hens and 5 groups of 5 hens each. The hens were reared in individual cages and fed the diet containing $8,000 \mathrm{ppm}$ of CTC for 7 days and thereafter fed the basal diet free from antibiotics for another 7 days.

All of the eggs laid by 10 hens of the first group during the experimental period of 14 days were kept individually in a refrigerator of $-20^{\circ} \mathrm{C}$. Among the 10 hens of the group, 5 hens, who laid more eggs continuously during 14 days of experimental period than the rest of the hens, were selected and all of the eggs laid by them during 14 days of experimental period were analyzed for their CTC content.

At $0,1,2,3$ and 5 days after the withdrawal of dietary CTC, i. e. at 7, 8, 9, 10 and 12 days after the start of the experiment, one group each of 5 hens was sacrificed to get the sample of the liver.

Individual egg white, egg yolk and the liver were homogenized and diluted by 5 times with $0.1 \mathrm{M}$ phosphate buffer solution of $\mathrm{pH} 4.5$. Content of CTC in the diluted sample was determined by cup-plate method using Bacillus cereus var. mycoides ATCC 
$11778^{4}$. The threshold sensitivity of the assay was $0.05 \mu \mathrm{g}$ equivalent per $\mathrm{g}$ of the sample. The content of CTC in the whole egg was calculated from the contents in the egg white and yolk as described previously ${ }^{2}$.

Content of CTC in the whole egg during the feeding period of CTC and after the withdrawal of dietary CTC was analyzed statistically as randomized block design, using individual hen as block. Data of 5 th day after the start of the experiment were discarded since only 2 hens out of 5 laid on that day. Content of CTC in the whole egg of other days, when no egg was laid, was estimated statistically by the procedure to estimate missing value in factorial experiment design ${ }^{5}$. Then, three regression analyses were carried out, i. e. the regression between CTC content in the eggs and days after the start of feeding 8,000 ppm of CTC, the regression between logarithm of CTC content in the egg and days after the withdrawal of dietary CTC, and the regression between CTC content in the liver and days after the withdrawal of the dietary antibiotic.

\section{Results}

Content of CTC in egg white and egg yolk of the eggs laid during feeding the diet containing 8,000 ppm of CTC and after the withdrawal of dietary CTC is shown in Table 1. After estimating the missing value statistically and discarding the data of 5th day, average of 5 estimates in egg yolk, egg white and whole egg are plotted in Fig. 1, to show the daily change in CTC content in the egg.

The incdease in CTC content in egg white was very rapid and reached plateau

Table 1. Chlortetracycline content in egg white and yolk of hens fed the diet containing $8,000 \mathrm{ppm}$ of chlortetracycline ${ }^{1)}$ ( $\mu$ g equivalent/g)

\begin{tabular}{lccccccccccccccc}
\hline Hen & \multicolumn{1}{c}{ Days on CTC2) feeding } & \multicolumn{1}{c}{ Days after withdrawal } \\
\hline No. & 1 & 2 & 3 & 4 & 5 & 6 & 7 & 1 & 2 & 3 & 4 & 5 & 6 & 7 \\
\hline Egg white: & & & & & & & & & & & & \\
$\quad 1970$ & 0.13 & 0.27 & 0.28 & 0.43 & $-3)$ & 0.32 & 0.20 & 0.14 & 04 & 0 & 0 & 0 & 0 & 0 \\
1971 & 0.10 & - & 0.13 & 0.15 & 0.19 & 0.21 & 0.18 & 0.10 & 0 & 0 & - & 0 & 0 & 0 \\
1972 & 0.26 & 0.29 & 0.44 & 0.36 & - & 0.39 & 0.31 & 0.16 & 0.05 & 0 & 0 & 0 & 0 & 0 \\
1981 & 0.14 & 0.24 & 0.31 & 0.24 & - & 0.17 & 0.20 & 0.11 & 0 & 0 & 0 & 0 & 0 & 0 \\
1983 & 0.15 & 0.42 & 0.31 & - & 0.21 & 0.31 & 0.28 & 0.11 & 0.06 & - & 0 & 0 & 0 & 0 \\
Egg yolk: & & & & & & & & & & & & & & \\
1970 & 0 & 0.06 & 0.11 & 0.18 & - & 0.27 & 0.28 & 0.24 & 0.21 & 0.19 & 0.12 & 0.09 & 0 & 0 \\
1971 & 0 & - & 0.06 & 0.06 & 0.09 & 0.11 & 0.14 & 0.17 & 0.18 & 0.14 & - & 0.06 & 0 & 0 \\
1972 & 0 & 0.08 & 0.14 & 0.30 & - & 0.39 & 0.39 & 0.39 & 0.47 & 0.32 & 0.19 & 0.08 & 0 & 0 \\
1981 & 0 & 0.09 & 0.13 & 0.28 & - & 0.38 & 0.28 & 0.28 & 0.28 & 0.23 & 0.18 & 0.08 & 0 & 0 \\
1983 & 0 & 0.08 & 0.13 & - & 0.17 & 0.27 & 0.28 & 0.30 & 0.25 & - & 0.18 & 0.09 & 0 & 0 \\
\hline
\end{tabular}

1) Threshold sensitivity was $0.05 \mu \mathrm{g}$ equivalent/g.

2) Chlortetracycline

3) No egg was laid.

4) Zero indicates the content below the sensitivity level. 


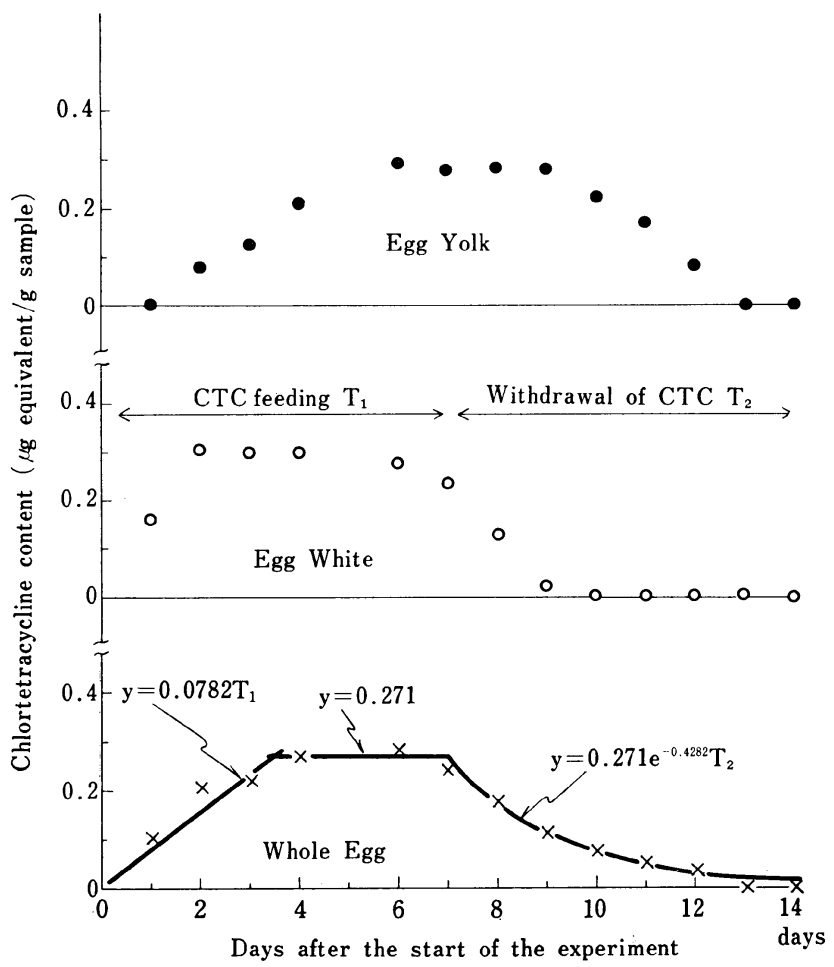

Fig. 1. Chlortetracycline content in the eggs laid by hens fed the diet containing $8,000 \mathrm{ppm}$ of chlortetracycline

already on the 2nd day of CTC feeding. After the withdrawal of dietary CTC, content of CTC in egg white decreased rapidly and only small amount of CTC, i. e. 0.05 and $0.06 \mu \mathrm{g}$ equivalent/g, which is equal to and only $0.01 \mu \mathrm{g}$ over the threshold sensitivity level, respectively, was found in 2 eggs out of 5 on the 2nd day after the withdrawal of CTC. On the other hand, CTC content in egg yolk increased almost linearly after feeding CTC, reached plateau on the $5^{\text {th }} \sim 6^{\text {th }}$ day on CTC feeding, and decreased almost linearly after the 3rd day of the withdrawal of dietary CTC.

Combining the contents in egg white and egg yolk, content of CTC in whole egg was found to increase rapidly and reached plateau on the 3rd day of CTC feeding. Thereafter CTC content during feeding period was almost constant with average value of $0.271 \mu \mathrm{g}$ equivalent/g. The following Equation 1 was found fit to describe the linearly increasing tendency of CTC in the eggs after feeding CTC,

$$
y=0.015+0.0782 T_{1}
$$

where, $T_{1}$ is days on CTC feeding and $y$ is average CTC content ( $\mu$ g equivalent/g) in whole egg laid at $T_{1}$ day. The correlation coefficient was 0.970 , which is significant at $5 \%$ level. However, the constant in Equation 1, i. e. 0.015 , was not significant statistically, so the relationship between $T_{1}$ and $y$ could be simply described by Equation 2 .

$$
y=0.0782 T_{1}
$$

The intersection between Equation 2 and $\mathrm{y}=0.271$, i. e. average CTC content at 
plateau, was 3.5 days.

The decrease in CTC content in the whole egg after the withdrawal of dietary CTC could be well described by the following Equation 3,

$$
\log y=-0.5672-0.1860 T_{2} \text {. }
$$

where, $T_{2}$ is days after the withdrawal of dietary CTC and $y$ is average CTC content ( $\mu \mathrm{g}$ equivalent/g) in whole eggs laid at $T_{2}$ day. The correlation coefficient was -0.993 , which was highly significant statistically at 1\% level. Equation 3 can be transformed into Equation 4, which is shown in Fig. 1.

$$
y=0.271 \cdot e^{-0.4282 T_{2}}
$$

Although CTC in egg white was detected for only 2 days after the withdrawal of diethdrawal of dietary CTC, the following Equation 5 was induced from the averages of CTC in egg white on 0,1 and 2 days after the withdrawal of dietary CTC,

$$
\log y=-0.4846-0.5536 T_{2}
$$

where, $T_{2}$ is days after the withdrawal of dietary CTC and $y$ is average CTC content ( $\mu$ g equlvalent/g) in egg white laid on $T_{2}$ day. Average CTC content of egg white at plateau, i. e., white of the eggs laid on the 2nd 3rd, 4th, 6th and 7th day on CTC feeding was used as the value for 0 day to get more reliable value than the actual average of data at 0 day. The correlation coefficient was fairly large, being -0.979 , but not significant statistically mainly due to the smallness of sample size, i. e. 3 .

Table 2. Chlortetracycline content in the liver of hens fed diet containing 8,000 ppm of chlortetracycline for 7 days ( $\mu \mathrm{g}$ equivalent/g)

\begin{tabular}{lcccc}
\hline \multicolumn{7}{c}{ Days after withdrawal of dietary chlortetracycline } & & \\
0 & 1 & 2 & 0 & 5 \\
\hline 6.00 & 0.26 & 0.29 & 0 & 0 \\
3.41 & 0.28 & 0.31 & 0 & 0 \\
3.10 & 0.38 & 0.30 & 0 & 0 \\
3.30 & 0.26 & 0.25 & 0 & 0 \\
3.38 & 0.49 & 0.34 & 0 & 0 \\
\hline
\end{tabular}

1) Zero indicates the content below the sensitivity level of $0.05 \mu$ g equivalent/g.

Content of CTC in the liver of the hens after the withdrawal of dietary CTC of $8,000 \mathrm{ppm}$ is shown in Table 2. Linear relationship between logarithm of average content of CTC in the liver of 5 hens and days after the withdrawal of dietary CTC was observed. The relationship could be well described by the following Equation 6, which can be transformed into Equation 7 .

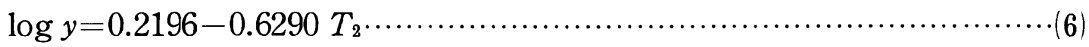

$$
\begin{aligned}
& y=1.66 \cdot e^{-1.4483 T_{2}}
\end{aligned}
$$

where, $T_{2}$ is days after the withdrawal of dietary CTC and $y$ is average CTC content ( $\mu$ g equivalent/g) in the liver at $T_{2}$ day. Correlation coefficient between $T_{2}$ and $\log y$ was -0.992 , which was highly significant statistically at $1 \%$ level. 


\section{Discussion}

In the previous experiments with spiramycin ${ }^{1)}$, tylosin ${ }^{2)}$ and oxytetracycline ${ }^{31}$, content of antibiotics in whole egg laid by the hens fed the diet of extremely high level of the antibiotics increased linearly within 7 days of feeding period. These findings do not mean that the content of the antibiotics in the egg increases without limitation. Instead, they rather mean that content of the antibiotics in the egg should reach plateau when the speed of absorption of dietary antibiotics into hens' body and that of disappearance from hens' body are in balance. The latter speed is a function of body deposition of the antibiotics. Therefore, the speed will be accerlated by the increase of body deposition by longer feeding of antibiotics. It is certain that 7 days of feeding spiramycin at dietary level of $1,000 \mathrm{ppm}$, tylosin st $8,000 \mathrm{ppm}$ and oxytetracycline at 4,000 ppm were not long enough to reach plateau of content of the antibiotics in the egg. However, 3.5 days of feeding CTC at 8,000 ppm was enough to reach plateau.

The findings reveal that the speed of absorption of CTC is slower, or the speed of disappearance of CTC from the hens' bcdy is more rapid than those of the other 3 antibiotics tested already, resulting in earlier balance between absorption and disappearance of CTC than that of the other antibiotics.

It should be mentioned that maximum content of CTC in whole egg at plateau was $0.271 \mu \mathrm{g}$ equivalent/g with dietary CTC level of $8,000 \mathrm{ppm}$, while content of oxytetracycline in whole egg on the 7th day on feeding $8,000 \mathrm{ppm}$ of oxytetracycline was estimated to be $1.98 \mu \mathrm{g}$ equivalent/g from Equation 2 or 8 in the previous paper ${ }^{3}$, although the value may be lower than the maximum value at plateau. Considering the values together with the difference in the behaviour of CTC and the other 3 antibiotics it is easily supposed that no CTC will be detected in both egg white and yolk of the eggs laid by hens fed the diet containing $20 \mathrm{ppm}$ of CTC, which is the dose allowed to use in feed for growth promoting purpose. Though only $8,000 \mathrm{ppm}$ of dietary level of CTC was tested in this experiment, it is also suspected that little CTC will be detected from the eggs laid by hens fed the diet containing $500 \mathrm{ppm}$ of CTC, which will be close to the upper level of CTC for therapeutic use. The findings on the residue of CTC in broiler' support the above supposition.

Combining Equations 2 and 4, following Equation 8 is induced to describe the behaviour of CTC in the eggs during and after feeding CTC at dietary level of $8,000 \mathrm{ppm}$,

$$
y=0.0782 T_{1} \cdot e^{-0.4282 T_{2}}
$$

where, $T_{1}$ is days on CTC feeding, $T_{2}$ is days after the termination of CTC feeding, and $y$ is average CTC content ( $\mu \mathrm{g}$ equivalent/g) in the whole eggs laid at $T_{1}+T_{2}$ days after the start of CTC feeding. In Equation 8, $T_{1}$ should be less than or equal to 3.47 days regardless of the length of CTC feeding over 3.47 days. In Equation 8, $T_{2}$ should be zero during CTC feeding and $T_{1}$ should be a fixed value after the termination of CTC feeding.

Equation 8 for CTC, though it does not contain the term of $\mathrm{x}$, i. e. dietary concentration of CTC, corresponds to Equation 1 for spiramycin, Equation 9 for oxytetracycline 
in the previous paper ${ }^{31}$ and Equation 9 for tylosin in the previous paper ${ }^{2}$. From these 4 equations, average content of antibiotics in the whole eggs laid by the hens fed the antibiotics at a certain dietary level for certain days can be calculated. For example, if $8,000 \mathrm{ppm}$ of antibiotics was fed for 3 days for therapeutic purpose, though the level is unusually high from the practical point of view, average content of spiramycin, tylosin, oxytetracycline and chlortetracycline in the whole eggs laid on the 3rd day of antibiotic feeding will be estimated to be $8.3,2.8,0.8$ and $0.2 \mu \mathrm{g}$ equivalent/g, respectively.

Since no term for $\mathrm{x}$, i. e. dietary concentration of CTC, is included in Equqtion 8, the easiness of dietary CTC to be transferred into egg cannot be compared with those of the other antibiotics, as we compared those of oxytetracycline and spiramycin in the previous paper $^{3}$.

As discussed repeatedly in the previous papers ${ }^{1 \sim 4}$, the coefficient for $T_{2}$ in Equations 3 and 6 indicates the rapidness of disappearance of CTC from whole egg and from the liver, respectively, after the withdrawal of dietary CTC. To understand the rapidness more easily, biological half lives and their 95\% confidence intervals were calculated and are shown in Table 3, with biological half lives of the other antibiotics for the convenience to compare. Biological half life of CTC in egg white could also be estimated from Equation 5, but its confidence interval was not calculated, since correlation coefficient was not significant statistically as mentioned above.

Table 3. Biological half lives of various antibiotics.

\begin{tabular}{clcc}
\hline \multirow{2}{*}{ Antibiotics } & calculated from & mean & $\begin{array}{c}\text { Biologicalhalf life } \\
9 \% \text { confidence } \\
\text { interval }\end{array}$ \\
\hline \multirow{3}{*}{ chlortetracycline } & whole egg & day & day \\
& egg white & 1.6 & $1.7 \sim 1.5$ \\
& liver (layer) & 0.5 & -1 ) \\
& whole egg & 0.5 & $0.6 \sim 0.4$ \\
\hline Oxytetracycline $^{2)}$ & egg white & 1.1 & $1.6 \sim 0.8$ \\
& whole egg & 0.6 & - \\
\hline Tylosin $^{3)}$ & egg white & 1.3 & $1.8 \sim 1.0$ \\
& liver (layey) & 0.6 & - \\
& liver (broiler) & & - \\
& whole egg & 0.6 & $0.9 \sim 0.4$ \\
\hline Spiramycin $^{5)}$ & egg white & 0.6 & $4.7 \sim 1.6$ \\
& liver (layer) & 2.4 & $3.6 \sim 1.8$ \\
& liver (broiler) & & $4.6 \sim 1.6$ \\
& & 2.4 & - \\
\hline
\end{tabular}

1) No interval was estimated since the exponential relationship was not confirmed statistically.

2) Literature 3.

3) Literature 2 .

4) Literature 6.

5) Literature 1.

6) Literature 4 . 
As shown in Table 3, biological half lives of CTC in the liver and egg white are almost identical, being 0.5 days in average, while that in whole egg is longer, being 1.6 days. The findings that biological half lives of CTC in whole egg, egg white and in the liver resemble those of tylosin suggest that CTC disappeares from the hens' body as fast as tylosin dose, but much faster than spiramycin does. As discussed previously ${ }^{2}$, antibiotics content in whole egg is important from the viewpoint of pollution of table egg. The biological half life of CTC in wholo egg was 1.6 days in average, which is almost comparable to those of oxytetracycline and tylosin, since their confidence intervals overlapped each other.

\section{Summary}

A diet containing extremely high level of $8,000 \mathrm{ppm}$ of chlortetracycline (abbreviated CTC) was fed to 35 laying hens for 7 days, and thereafter, the hens were fed the basal diet free from CTC for another 7 days. Five hens each were sacrificed on $0,1,2,3$ and 5 days after the termination of CTC feeding to analyze CTC content in the liver micro-biologically. Among the rest of the hens, 5 hens, who laid more eggs continuously for 14 days than the others, were selected and CTC content of all of the eggs laid by them were analyzed.

Content of CTC in egg white and whole egg increased rapidly after feeding CTC and reached plateau on the 2nd and 4th day, respectively. After the withdrawal of dietary CTC, the content of CTC in whole egg, egg white and the liver decreased exponentially.

Combining the data, an equation was induced to describe the behaviour of dietary CTC at 8,000 ppm, which resembles that of tylosin.

Biological half life of CTC in whole egg was calculated to be 1.6 days with $95 \%$ confidence interval from 1.7 to 1.5 days, and that in the liver to be 0.5 days from 0.6 to 0.4 days.

\section{Literature}

1) Yoshida, M., D. Kubota, S. Yonezawa, H. Nakamura, H. Azechi and N. Terakado: Japan. Poultry Sci., 8, 103, 1971.

2) Yoshida, M., D. Kubota, S. Yonezawa, H. Nakamura, R. Yamaoka and H. Yoshimura: ibid., 10, 29, 1973.

3) Yoshida, M., D. Kubota, S. Yonezawa, H. Nakamura, R. Yamaoka and H. Yoshimura: ibid., 10, $254,1973$.

4) Yoshida, M., S. Yonezawa, H. Nakamura, H. Azechi, N. Terakado and T. Horiuchi: ibid., 8, 94, 1971.

5) DAvis, O.L.: The design and analysis of industrial experiments. 2nd ed., Oliver and Boyd, London 1956.

6) Yoshida, M., H. Hoshi, S. Yonezawa, H. Nakamura, R. Yamaoka: Japan. Poultry Sci., 10, 23, 1973. 


\title{
飼料中のクロルテトラサイクリンの鵎卵中への移行ならびに
}

舀卵之肝臓よりの消失について

\author{
吉田 実* ・窪田 大作 ${ }^{*} \cdot$ 米沢 昭一** \\ 中村 久 $^{* *}$. 山岡 良三** ${ }^{*}$ 吉村 治郎 ${ }^{* *}$ \\ * 農林省畜産試験場，千葉市 \\ ** 農林省動物医薬品検査所，国分寺市
}

\begin{abstract}
クロルテトラサイクリン（以下 CTC）の極端な高濃 度 $(8,000 \mathrm{ppm})$ を含む飼料を，産卵䳕 35 羽に 7 日間給 与し, その後, CTC 無添加飼料をさらに 7 日間与えた。 CTC 給与中止後 $0,1,2,3$ および 5 日に，それぞれ 5 羽ずつ殺して肝蔵中の CTC 含量を微生物定量法により 測定した。残りのうち, 14 日間の産卵数の多い 5 羽を選 び，その 14 日間の卵をすべて分析に供した。

卵白および全卵中の CTC 含量は, CTC 給与開始後 急速に増加し，それぞれ 2 および4 日目にほぼ一定值と
\end{abstract} なった。CTCの給与を中止すると，全卵，卵白和よび
肝臟中の CTC 含量は指数曲線的に減少した。 これらのデータを総合することにより，8,000 ppm の CTC を与光る場合の 飼料中の CTC の動きを示す式を 導くことができた。これは，タイロシンの動きを示す式 と似ている。

全卵中の CTC の生物学的半隇期を計算すると, 1.6 日で，その $95 \%$ 信頼区間は $1.7 \sim 1.5$ 日であった。肝臓 中の CTC の半減期は 0.5 日で, $0.6 \sim 0.4$ 日の区間であ った。

（家禽会誌，10，261２68，1973） 